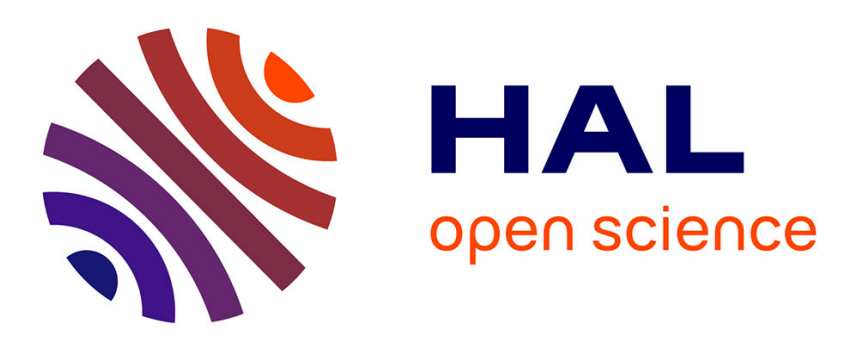

\title{
Drought avoidance by asynchronous flowering in pearl millet stands cultivated on-farm and on-station in Niger
}

\author{
Anneke de Rouw, Thierry Winkel
}

\section{To cite this version:}

Anneke de Rouw, Thierry Winkel. Drought avoidance by asynchronous flowering in pearl millet stands cultivated on-farm and on-station in Niger. Experimental Agriculture, 1998, 34 (1), pp.19-39. 10.1017/S0014479798001057 . ird-00142179

\section{HAL Id: ird-00142179 \\ https://hal.ird.fr/ird-00142179}

Submitted on 17 Apr 2007

HAL is a multi-disciplinary open access archive for the deposit and dissemination of scientific research documents, whether they are published or not. The documents may come from teaching and research institutions in France or abroad, or from public or private research centers.
L'archive ouverte pluridisciplinaire HAL, est destinée au dépôt et à la diffusion de documents scientifiques de niveau recherche, publiés ou non, émanant des établissements d'enseignement et de recherche français ou étrangers, des laboratoires publics ou privés. 
Expl Agric. (1998), volume 34, pp. 19-39

Printed in Great Britain

Copyright (C) 1998 Cambridge University Press

\title{
DROUGHT AVOIDANGE BY ASYNGHRONOUS FLOWERING IN PEARL MILLET STANDS GULTIVATED ON-FARM AND ON-STATION IN NIGER
}

\author{
By A. DE ROUW† and T. WINKEL \\ ORSTOM, Institut Français de Recherche Scientifique pour le Développement en \\ Coopération, BP 11416, Niamey, Niger
}

(Accepted 1 July 1997)

\begin{abstract}
SUMMARY
The effects of pre-flowering drought on millet were studied in two experiments, an on-station, dry-season trial under irrigation and an on-farm trial where drought was induced by natural rainfall regimes (one wet, two dry years). The on-station experimental conditions were adjusted to those of Sahel farms, particularly through low plant density, low soil fertility and an irrigation regime that simulated the natural rainfall pattern. The replanting $(5-10 \%)$ of missing hills in the on-farm trial increased stand variance significantly, whereas small quantities of applied $\mathrm{N}$ reduced it. Grain yield and grain number were equally seriously affected by drought in both experiments; yields were $700-800 \mathrm{~kg} \mathrm{ha}^{-1}$ in the control years compared with $200-300 \mathrm{~kg} \mathrm{ha}^{-1}$ in drought years. Both experiments showed sub-populations of early-, intermediate- and lateflowering millet plants. Fertile tillers were concentrated in the group of early-flowering plants. Only this group when subjected to moisture stress could secure part of the grain production by delaying, to a maximum of $18 \mathrm{~d}$, the development of fertile tillers beyond the period of stress. Later-flowering plants, mostly uniculm, would be either sterile or unaffected by drought, depending on the exact coincidence of panicle development and drought. Drought did not alter the number of fertile hills per stand, because earlier- or later-flowering plants in the same hill compensated for sterile plants. The period of flowering in a stand was stretched over $40-45 \mathrm{~d}$ independently of drought, and this occurred both in the on-station experiment comprising 19 plants per treatment and in the on-farm experiment comprising about 700 hills. Although stand variance was reduced by better crop management and resulted in more fertile hills, more panicles per hill, and taller hills of more uniform height, the spread in flowering period of the millet population tended to be unaffected. Stand variability therefore appeared to be of paramount importance in accounting for drought avoidance.
\end{abstract}

\section{INTRODUGTION}

Pearl millet (Pennisetum glaucum (L.) R. Br.) is usually grown as a rain-fed crop in semi-arid regions in West Africa and India. In the Sahel (250-600 mm precipitation) it is the most important crop; in the Sudanian Zone (600-1000 $\mathrm{mm}$ ) it is of equal status with sorghum. The great merit of millet is that it will give economic although low yields in soil conditions too poor to support other cereals. The chief characteristic of the Sahel is that it is prone to frequent and lengthy periods of drought. Though poor soils keep the production level low

$\nmid$ Present address: Department of Agronomy, INAPG, 78850 Thiverval-Grignon, France.

Fonds Documentaire oRSTOM

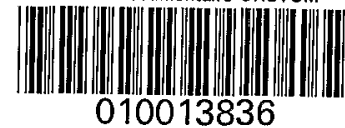

Fonds Documentaire ORSTOM Cote: $B * 13836 \mathrm{Ex}: \mathcal{A}$ 
droughts, especially intermittent dry spells, threaten the whole operation. If severe, these droughts affect development stages such as initiation of panicles and flowers and can lead to complete crop failure.

\section{Drought resistance and drought avoidance}

Plants can succeed in dry regions by either avoiding the periods of idrought or by resisting them. The drought resistance of pearl millet is rather low as it lacks particular adaptations to dehydration such as osmotic adjustment and high tissue resistance (Squire et al., 1984; Do et al., 1996). Millet also has one of the highest leaf conductances of all $\mathrm{C}_{3}$ and $\mathrm{C}_{4}$ grasses (Korner et al., 1979), making its water use high, compared with legumes and weeds growing in the same area. A definite adaptation of pearl millet to withstand drought is its deep root system (Chopart, 1980).

Drought avoidance relies primarily upon the synchronization of the life cycle to periods when there is a high probability of satisfactory conditions for growth. For pearl millet, this has resulted in a large range of maturity types, selected by farmers and breeders to match the crop phenology to the average water supply of the environment (Bourke, 1963). Secondly, drought avoidance can be achieved by varying the duration of a growth period depending on the extent of water deficits, a characteristic currently called 'development plasticity' (Ludlow and Muchow, 1988). In millet, early and asynchronous development of panicles and flowers has the potential to spread flowering over a long period, maintaining the yield potential even if the main stem is damaged (Mahalakshmi et al., 1987). Furthermore, development plasticity in millet is associated with 'growth plasticity'. This means that when water is available and nutrients are not limiting, the plant produces great quantities of leaves and stems. Pearl millet can store up to $70 \%$ of its biomass in tillers (Azam-Ali et al., 1984). This 'capital' of biomass and nutrients stays 'liquid' during most of the cropping cycle and it serves as a buffer against fluctuations of the environment (Siband, 1983). If moisture stress occurs, transpiration is reduced by reducing the green leaf area (Wallace et al., 1990; Soegaard and Boegh, 1995).

A number of studies describe how pearl millet withstands periods of drought (for reviews, see Pearson, 1984; Ludlow and Muchow, 1988; Winkel and Do, 1992), and quite an effort has been made to survey, select and breed millet cultivars in order to match the crop phenology to the average water supply of the environment (Kowal and Kassam, 1978). The other side of drought avoidancespreading the sensitive periods over time - has received some attention in morphophenological studies, but agronomic studies are scarce.

\section{Agrophysiology and agronomy}

The experimental conditions used in agrophysiology and in agronomy, especially in on-farm research, can be so different from each other that the results become difficult to reconcile. Most important are planting distance, soil fertility 
and water regimes, as they greatly influence plant form and development (AzamAli et al., 1984) and consequently the crop adjustment to water stress.

High plant densities $\left(>100000\right.$ plants ha ${ }^{-1}$ ) are customary for physiological trials (Garg et al., 1993; Squire et al., 1986) and where low densities are used, similar to farmers practice (approximately 30000 plants $^{-1} \mathrm{a}^{-1}$ ), it is stated that the crop is planted sparsely (Do et al., 1996; Wallace et al., 1990). High plant densities leave the development of the main stem unaffected but tiller formation is greatly reduced (Carberry et al., 1985). Consequently few tillers become fertile and almost all of the grain yield is concentrated in the main shoot. In the Sahel, the farmers' practice of low plant densities favours tillering (Adamou, 1994; McIntire and Fussell, 1989) and so the fertile tillers can contribute to the grain yield. When water supply during panicle or floral initiation is uncertain, plants in high- and low-density stands run different risks. In high-density stands with only the main stem producing flowers, there is only one chance for successful reproduction. In low-density stands, the panicles on tillers develop asynchronously and the risk of crop failure is reduced.

Millet experiments are carried out under a wide range of fertility levels. With an input of 80-120 kg N ha- ${ }^{-1}$, plants can survive up to 50 consecutive days of drought(Garg et al., 1993) and grain production of stressed plants may still reach $3000 \mathrm{~kg} \mathrm{ha}^{-1}$ (Seetharama et al., 1984). This is in contrast to Sahelian farmers who use practically no fertilizers. Actual grain yields in Niger in drought and normal rainfall years range between 150 and $550 \mathrm{~kg} \mathrm{ha}^{-1}$ (McIntire and Fussell, 1989). Extra nutrient input not only implies extra biomass produced and higher water requirements but it also influences developmental processes. Application of nitrogen, and particularly in combination with phosphorus, stimulates tillering (Siband, 1981), early flowering and tiller fertility (Traoré, 1974). Thus with the quantities of nutrients applied, the drought-sensitive periods of panicle and flower development can be manipulated.

Physiological studies on drought stress usually have recourse to irrigation. Generally, little attention is paid to frequency, duration and techniques of water supply, for the chief concern is that control plants stay free from moisture stress. Irrigation to field capacity from emergence to maturity enables plants to initiate many tillers and for late tillers to set seed (Mahalakshmi and Bidinger, 1985). In African rain-fed cultivation, the rainy season determines the duration of the millet cycle. It is characterized by a tendency for rainfall to taper off towards the end of the season (Sivakumar, 1989). In the natural environment, spacing, nutrients and rainfall, will set the limits for the number of fertile tillers and the period of flowering and thus to the 'plastic' response of millet

The problems in the integration of agrophysiological and agronomic studies are not only practical, but also conceptual. In physiological studies, the individual plant is the centre of interest (Gross, 1989; Winkel et al., 1997). Millet plants are commonly grown together in small plots and basic data are measurements per plant (that is, control plants are compared with stressed plants). From this viewpoint, the plant responds to stress through physiological, morphological and 
phenological adjustments. Agronomic studies are concerned with populations and basic data are measurements per plot surface. Although the millet crop is usually planted in one day, all plants are not in the same developmental stage. Millet fields are known for their great within-stand variability. When stress occurs, only part of the population is at a stage where it suffers maximum damage from water deficit. Other individuals have just passed that stage or have not yet reached it. The agronomist is inclined to attribute most of the drought avoidance to the variability of the stand, as some plants always seem to be able to avoid the worst conditions and produce some grain. Development plasticity per se - how an individual plant compensates for yield losses - remains invisible in agronomic studies, while in agrophysiology, within-stand variation is given little consideration.

\section{Stand variability}

One obvious source of within-stand variation is genetic because pearl millet is cross-pollinated. This applies to all millet experiments. A second major source of stand variation is cultivation, mainly planting density and fertilization. In onstation plots millet is often planted individually in rows (Garg et al., 1993; Squire et al., 1986). This is in contrast to Sahelian farmers who always plant in hills. Hill planting consists of making a hole to a depth of $5-10 \mathrm{~cm}$ using a traditional hoe, placing 20-50 seeds in each hole and covering immediately. One or two reseedings are necessary to fill in missing hills (Klaij and Hoogmoed, 1993). Local farming not only produces hills of different ages, but also plants of different ages within a hill. Emergence in hills is phased because the seeds are buried at different depths (Jouve, 1991). A third source of variation constitutes the environment. Millet fields in Niger are variable because the soil surface is heterogeneous both physically, for example, micro-relief and crusted surfaces, (Geiger and Manu, 1993) and chemically (Brouwer et al., 1993; Chase et al., 1989). Furthermore, where fields are located on sloping land a yield gradient is induced by the topographical position of the planted area (Rockström and De Rouw, in press).

Stand variability in pearl millet is currently being studied by agronomists working with low fertility and low planting densities at ICRISAT in Niger. These studies investigate important sources of variability in order to clarify treatment effects on millet growth (Buerkert et al., 1995) as well as some cultivation techniques that can lead to a more uniform stand (Buerkert and Stern, 1995). Lamers and Feil (1995) provide complementary information at a field and at a farm level, enumerating many sources of millet stand variation and their repair. In these studies, stand variability, or more precisely 'spatial crop growth variation', is understood as variation in grain yield, in total numbers of panicles, and in final biomass production of neighbouring hills. Yet stand variability can also be assessed in terms of development phases and phenology, and in this area very little published data exists. Still more important is the lack of information on how a population of millet at different stages of development reacts to rainfall 
hazards. In other words, stand variability, besides being a problem for the researcher, can be a problem or an advantage to the farmer.

Despite the methodological differences between studies at the plant and population levels, they need to be compared and synthesized, otherwise there is no progress in our understanding. This paper compares the results of two experiments designed to study drought avoidance in millet, one on-station, dryseason experiment under irrigation, the other on-farm, with stress induced by natural rainfall regimes over three rainy seasons. The main points considered are: (i) how to integrate and complement on-station and on-farm results and (ii) what part of drought avoidance can be attributed to the plasticity of the individual plant and what part can be attributed to stand variability.

\section{MATERIALS AND METHODS}

The experimental conditions of plant density, fertility level and water regime which were suspected of interacting with the millet response to drought were given special consideration. In the on-station agrophysiological experiment, similarities to Sahelian farm conditions were: choice of a local landrace, use of hand tools for planting and weeding, hill planting, low plant density and sandy soil. However, some fertilizer application was needed to even out the residual soil variation of the preceding experiment, and the natural rainfall pattern of an average cultivation season was simulated by irrigation. Seasonal patterns of the solar radiation, air temperature, and vapour pressure deficit are shown in Fig. 1.

Generally, on-farm experiments are closer to the natural environment in terms of soil, climate and rainfall hazards, but the sandy soils in Niger are likely to be deficient in phosphorus and likely to obscure the treatment effects. For this reason a single application of superphosphate was applied each year.

\section{Location}

The on-station experiment was carried out at the Institut des Radio-Isotopes (IRI), University of Niamey, Niger (lat $13^{\circ} 29^{\prime} \mathrm{N}$ long $2^{\circ} 10^{\prime} \mathrm{E}$ ). Soils are thick flatterrace sands, containing $96 \%$ sand and $1.7 \%$ clay in the top $50 \mathrm{~cm}$, and further down $(50-150 \mathrm{~cm}), 93 \%$ sand and $4.8 \%$ clay. The topsoil is somewhat acid $(\mathrm{pH}$ $\mathrm{H}_{2} \mathrm{O} 5.7$ ) and poor in total nitrogen (104 ppm) and total phosphorus (88 ppm). Soil samples were taken before cultivation and fertilization.

The on-farm experiment was conducted $65 \mathrm{~km}$ east of Niamey, $5 \mathrm{~km}$ from the village of Banizoumbou (lat $13^{\circ} 32^{\prime} \mathrm{N}, 2^{\circ} 41^{\prime} \mathrm{E}$ ). Soils are very thick (over $9 \mathrm{~m}$ ) aeolian sand deposits. The texture changes gradually from $96 \%$ sand and $2.3 \%$ clay in the topsoil $(0-50 \mathrm{~cm})$ to $92 \%$ sand and $7.2 \%$ clay at a depth of $150 \mathrm{~cm}$. The topsoil is acid ( $\mathrm{pH} 4.9)$, and poor in total nitrogen (127 ppm) and total phosphorus $(50 \mathrm{ppm})$. Soil samples were taken at harvest in 1992, 1993 and 1994, and years were combined. These low levels of fertility are quite normal for sandy soils cultivated with millet (McIntire and Fussell, 1989). The soil surface 

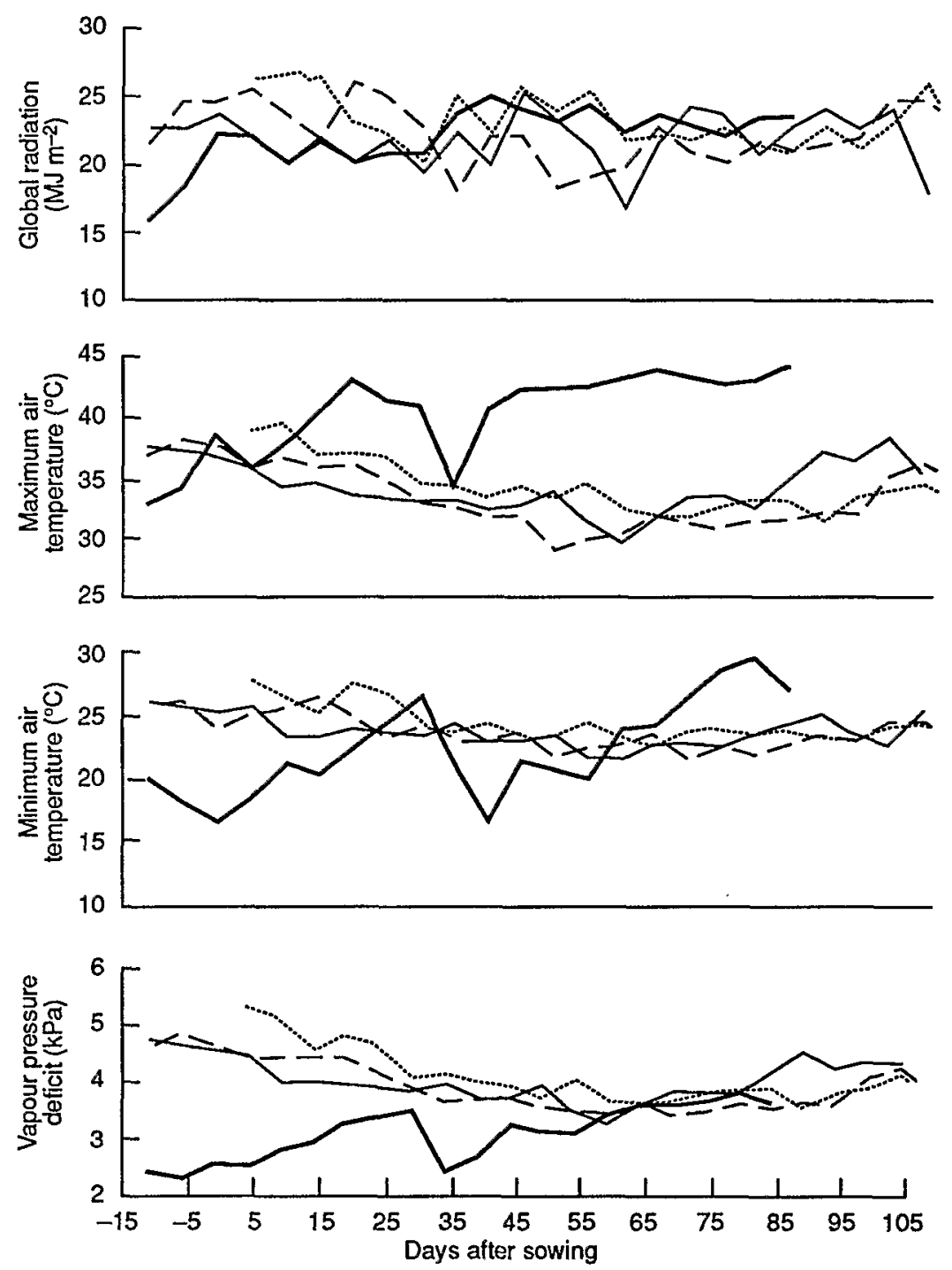

Fig. 1. Seasonal patterns of solar radiation, air temperature and vapour pressure deficit for four growing seasons (-, on-station sowing 10 February 1993 ; -, on-farm sowing 30 June $1992 ;. . . .$. , on-farm sowing 3 June 1993; - -, on-farm sowing 5 June 1994. Data are 5-day averages.

was slightly crusted $(<3 \%)$ and there were relatively few shrubs $\left(450 \mathrm{ha}^{-1}\right)$. The field had been cultivated traditionally with millet each year since 1986 .

\section{Irrigation and rainfall}

Banizoumbou and Niamey lie in the same climatic zone (Sivakumar, 1989). The relatively cool dry season lasts from October to February, the hot dry season from March to May. Mean annual rainfall is about $560 \mathrm{~mm}$ in Niamey.

In Fig. 1 the meteorological data recorded at IRI (hot dry season) and 
Banizoumbou (rainy seasons) are combined so as to cover all four cultivation periods. Seasonal variations in global radiation were slight, yet important differences between the experiments concerned temperature and daily average vapour pressure deficit (VPD). In the dry-season experiment, VPD stayed at a low level up to about 50 days after sowing (DAS) because of the low night temperatures in February and March. Thereafter, VPD stabilized at $3.5-4.0 \mathrm{kPa}$, because the relative air humidity increased with the approach of the rainy season.

On-station, the control irrigation regime approximately simulated the average rainfall regime of the Tanout area, the origin of the landrace under study (Niger, lat $14^{\circ} 57^{\prime} \mathrm{N}$ long $8^{\circ} 49^{\prime} \mathrm{E}$ ). In the stress treatment, water was withheld during the period 35-50 DAS. The total quantity of water applied in the control plots was $396 \mathrm{~mm}$ and in the stressed plots $306 \mathrm{~mm}$, a deficit of $23 \%$. Water, applied by micro-sprinklers spaced at $1 \times 1 \mathrm{~m}$, was considered more natural than furrowirrigation or surface flooding often used in irrigation experiments.

On-farm, the total rainfall was $438 \mathrm{~mm}$ in 1992, a deficit of $21 \%$ compared with the long-term mean. Precipitation was, however, well distributed over the cropping cycle, so the 1992 season served as a control. Total precipitation in 1993 was $449 \mathrm{~mm}$ (19\% short of the mean), and in $1994701 \mathrm{~mm}$ (27\% above average). In 1993 and 1994 millet suffered from drought because the rainfall was ill distributed.

\section{Agronomic details}

On-station, the pearl millet was sown at a density of 1 hill $\mathrm{m}^{-2}$ on 10 February 1993 after $29 \mathrm{~mm}$ of irrigation. All hills had plants and hills were thinned to three plants per hill at $20 \mathrm{DAS}$. The non-photosensitive landrace, Ankoutess, was used which has a grain yield potential of $900-1000 \mathrm{~kg} \mathrm{ha}^{-1}$ when sown at $1 \mathrm{hill} \mathrm{m}^{-2}$ (INRAN, 1987). One day before sowing an application of $30 \mathrm{~kg} \mathrm{~N}+13 \mathrm{~kg} \mathrm{P}+$ $25 \mathrm{~kg} \mathrm{~K} \mathrm{ha}^{-1}$ was applied and, at thinning, an extra $15 \mathrm{~kg} \mathrm{~N} \mathrm{ha}^{-1}$ as urea was applied to prevent competition for nitrogen interacting with competition for water. Insect populations were controlled by frequent spraying and the entire field was protected against bird damage by a fishing net.

On-farm, the millet was sown with the first heavy rainstorm of the season (33 $\mathrm{mm}, 30$ June 1992; $52 \mathrm{~mm}, 3$ June 1993; $39 \mathrm{~mm}, 5$ June 1994). The density was fixed at 1 hill $\mathrm{m}^{-2}$ and thinning to three plants per hill took place at 21 DAS in 1992 and 1993, and at 31 DAS in 1994 because of severe drought. Hills with no germinated seedlings were re-seeded once $(1992,1993)$, or twice (1994) between emergence and thinning. The cultivar used was the non-photosensitive GIVT (Composite Inter-Variétal de Tarna). GIVT remains very similar to the traditional landraces while being a well-known test crop in Niger. Cultivated in the 450-650 mm rainfall zone at 1 hill $\mathrm{m}^{-2}$ it has a grain yield potential of 2500-2800 $\mathrm{kg} \mathrm{ha}^{-1}$ (INRAN, 1987). Each year in May, $10 \mathrm{~kg} \mathrm{P} \mathrm{ha}^{-1}$ as single superphosphate was applied. Insecticide was sprayed once a year during flowering and damage by insects and birds caused a $6 \%$ loss of panicles in 1992, $9 \%$ in 1993, and $14 \%$ in 1994. 


\section{Experimental design}

The on-station experiment was a complete block design with four water regimes and five replicates. Only two regimes are discussed here, the control and the prefloral stress regime. In each plot $(20 \times 4 \mathrm{~m})$ the two central rows were sampled. One of the three plants in each hill was randomly labelled at thinning and all observations were performed on this plant. Above-ground biomass was sampled destructively at 35 and 95 DAS in the control plots, and at 95 DAS in the stressed plots. The growth of the plants before the stress period was assumed to be identical to that of the control plants. Two hills were taken each time, and four at harvest 95 DAS. The dry weights of leaves, stems and panicles on tillers and the main stem were measured separately (oven dried at $80^{\circ} \mathrm{C}$ for 72 hours). At harvest, panicles were threshed and grain weight and grain number determined. The number of flowering panicles was recorded three times a week on the same four plants in each plot during the whole flowering period. Each plot was equipped with a neutron probe access tube to a depth of $170 \mathrm{~cm}$. Measurements were taken at regular depths every week from 14 DAS until harvest.

The on-farm experiment was a two-factor randomized complete block design (planting density and nitrogen application) with four replications. One density was identical to the on-station trial. The other densities are not considered here. Urea at $50 \mathrm{~kg} \mathrm{~N} \mathrm{ha}{ }^{-1}$ was applied in two equal fractions at approximately 30 and 60 DAS, depending on the rainfall. Elementary plots were $12 \times 12 \mathrm{~m}(10 \times 10 \mathrm{~m}$ harvest area). Missing hills were recorded four times between seven and 80 DAS. The re-seeded hills were marked on a map in order to distinguish the first seeding population from the re-seeded hills. Numbers of plants per hill (sample of 10 hills per plot) were counted before thinning. All millet hills received a development score seven days after thinning. There were six assessments and only the most developed plant in the hill was considered. Growth stages (after Maiti and Bidinger, 1981) were: 1 = five-leaf stage, only first and second leaf fully expanded; $2=$ five-leaf stage, emergence of tiller leaves; $3=$ five-leaf stage, tiller leaves well visible and plant is dark green in colour; $4=$ panicle initiation stage, the plant acquires a dome shape; $5=$ panicle initiation stage, many fully expanded dark green leaves; $6=$ panicle initiation stage, first internodes start to elongate. These scores were mapped too. The above-ground biomass on four hills per plot was determined in a similar manner to the on-station trial, at 35 DAS in 1992 and 1993, and at 45 DAS in 1994 because of severe drought. From 50 DAS onwards the presence of panicles was recorded on the same 10 hills per plot at weekly intervals in 1993 and 1994 but less frequently in 1992. At 80 DAS the maximum height and the total numbers of panicles per hill were recorded for all hills and mapped. At the final harvest 100 DAS in 1992, a normal year, and 115 DAS in 1993 and 1994, drought years, total grain yield, numbers of panicles with grain and single-grain weights were determined for each plot. The above-ground fresh biomass was weighed in the field, panicles and stover separately, and a sample was taken to be oven-dried, from which the percentage of moisture was calculated for each plot. 
Soil water content was measured with a neutron probe during the three seasons using four access tubes that were installed in the four replicates. Measurements were made at regular depths down to $3 \mathrm{~m}, 1,2,4$ and $7 \mathrm{~d}$ after each storm and further at weekly intervals during the whole rainy season.

\section{RESULTS}

\section{Number of hills}

On-station, over three millet plants emerged in every hill and all hills survived up to harvest, so the whole population germinated from the first seeding and after thinning all hills contained exactly three plants.

In the on-farm experiment missing hills occurred every year, but one or two reseedings kept the missing percentage between 5 and $15 \%$. Re-seeding not only made up for the hills where no plants emerged at 0-7 DAS, but also compensated for the disappearance of hills between emergence and thinning at 7-21 DAS. After thinning the density of hills remained stable up to the end of the season, except in 1994 when heavy rainstorms destroyed $6 \%$ of the hills. Prior to thinning the average number of plants per hill was 8.6 in 1992, 12.0 in 1993, and 4.1 in 1994, reflecting the early season water availability. After thinning mean numbers of plants in hills were largely the same: 2.6 plants per hill in 1992, and 2.8 in 1993 and 1994 . In the three years, the field carried a first-seeding population of $78 \%$ in $1992,90 \%$ in 1993 and $78 \%$ in 1994, as well as a re-seeded population of $9 \%$ in $1992,5 \%$ in 1993 and $6 \%$ in 1996. This represented an age gap of 7-20 d. Numerous hills carried only one or two plants.

The number of hills is not often used as a component of yield in on-station trials because unvegetated hills are rare or eliminated from the analysis (McIntire and Fussell, 1989). In traditional farming and on-farm research this component cannot be ignored, especially in low rainfall years. Klaij and Hoogmoed (1993) never recorded 100\% hill emergence and, without re-seeding, the first-seeding population averaged $77 \%$ of the sown surface depending on the rain in the preplanting period. Thereafter the number of hills with millet plants fell to only $48 \%$ at 60 DAS.

\section{Within-stand variance}

The on-station stand contained fertilized plants of a similar age. The effectiveness of these two practices to reduce population variance can be illustrated with the on-farm data, taking the maximum height of a hill at $80 \mathrm{DAS}$ as a variable. Mean maximum height and its standard deviation were determined for the firstseeding hills and for the whole population (first-seeding hills + re-seeded hills) in each plot and for each year. Because the number of hills in each plot varied (sample size), the variances of the four replicates were pooled (weighting by degrees of freedom). The pooled variances for all 12 populations are graphed in Fig. 2. In all three years, the even-aged, fertilized first-seeding population was the most uniform. When the re-seeded hills were added, forming a normal millet 


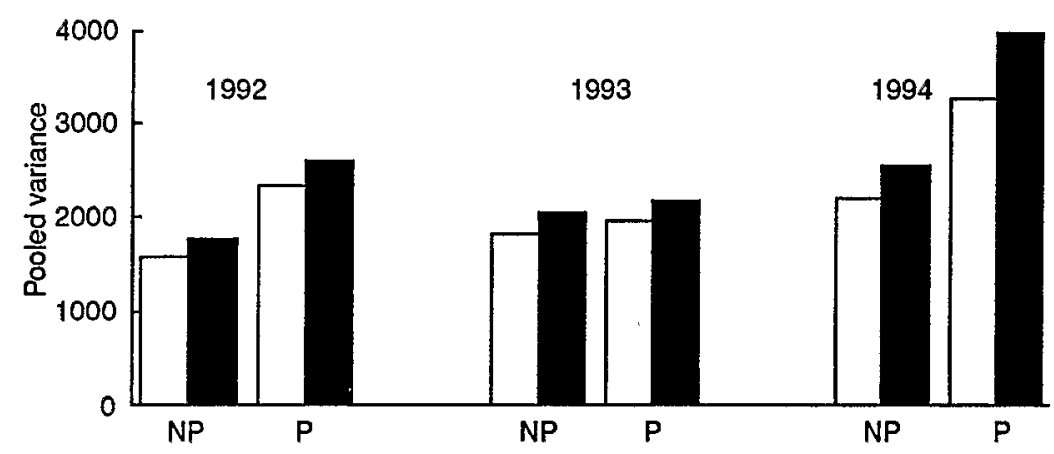

Fig. 2. On-farm, the pooled variance of maximum height of first-seeding hills $(\square)$ and all hills $(\square)$ at 80 days after sowing ( $n$ between 318 and 382) for plots receiving nitrogen and phosphorus (NP) or phosphorus (P) fertilization.

stand, population variance increased markedly. To test the influence of the reseeded hills on stand variance, a simple $t$-test (paired two-sample for means) was applied. The average height of re-seeded hills remained significantly lower than that of the first-seeding hills in all years in both the fertilized and the control plots (at the $1 \%$ level). This implied that the variance increased when re-seeded hills were incorporated into the plot population.

Absence of nitrogen fertilization greatly increased stand variance, especially in the 1992 and 1994 seasons. A test for homogeneity of variances was applied to compare the variability of fertilized and unfertilized stands (one tailed $\mathrm{H}_{\mathrm{A}}: \sigma_{\text {control }}^{2}$ $>\sigma_{\text {fert }}^{2}$ with $\mathrm{F}=\mathrm{s}_{\text {control }}^{2} / \mathrm{s}_{\text {fert }}^{2}$ ). In 1992 and 1994 , the millet population without fertilizer application was significantly more variable (at F 1\% level) than when nitrogen was applied, both for the even-aged first-seeding population and for the population including re-seeded hills. In 1993, the differences in variances were not significant (at F $5 \%$ level).

This example demonstrates the degree of uniformity that can be achieved by considering an even-aged millet population given nitrogen fertilizer. Buerkert and Stern (1995) in their analysis of within-plot variance, demonstrated that for millet under poor management an application of $13 \mathrm{~kg} \mathrm{P} \mathrm{ha}^{-1}$ gave a shift towards taller hills and more uniform heights. It is probable that most measurements of millet populations are subject to the same population rules. However, our hypothesis was that drought avoidance by asynchronous flowering lies partly in the variability of the stand. Stand variability tends to be reduced by nitrogen fertilization and in a population comprising no re-seeded hills. It was necessary to test whether this uniformity in the stand also reduced the spread in flowering period of the population.

\section{Seasonal water and millet production}

Fig. $3 \mathrm{a}$ and Fig. $3 \mathrm{~b}$ show the seasonal variation in total soil water content during the cultivation periods, for the on-station and the on-farm trials. Fig. $3 \mathrm{~b}$ 
(a)

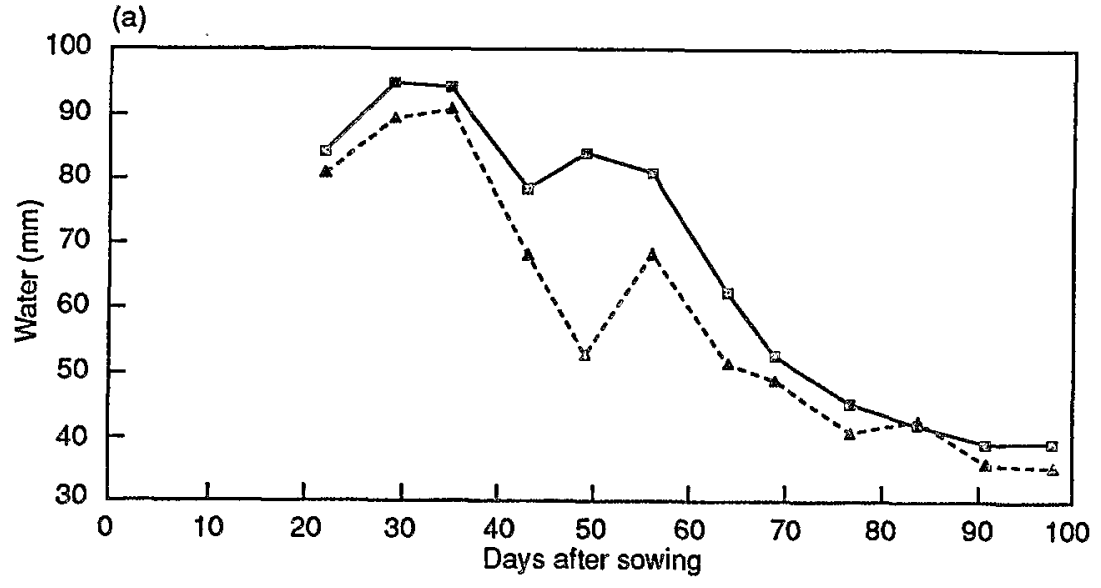

(b)

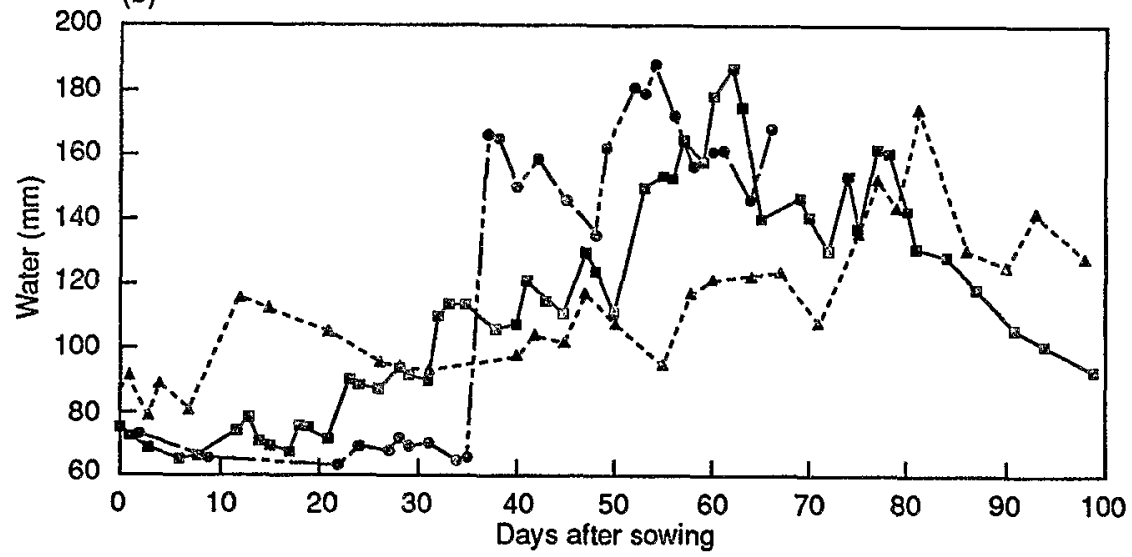

Fig. 3. (a) On-station, seasonal variation in soil water content $(0-170 \mathrm{~cm})$ during the growing season for control ( $\longrightarrow$ ) and stressed ( ${ }^{\left.-\mathbf{k}^{*}\right)}$ millet and (b) on-farm, seasonal variation in soil water content $(0-160$ $\mathrm{cm})$ during the three growing seasons $(-\mathbf{m}-1992 ; \cdots \mathbf{A} \cdot 1993 ;--\mathbf{- 1 9 9 4 )}$

shows periods of apparently sufficient water supply in 1992, and of early-season water shortage in 1993 (30-45 DAS), and 1994 (20-35 DAS). Excess water occurred in 1994 (36-60 DAS).

At $35 \mathrm{DAS}$, while entering the period of water stress, the mean dry weight of onstation millet was $36.6 \mathrm{~g} \mathrm{hill}^{-1}$, and mean tiller number 20.4 hill $^{-1}$. At 35 DAS the average dry weight of the on-farm hills was small in all years, $10.6 \mathrm{~g} \mathrm{hill}{ }^{-1}$ in 1992, 7.1 in 1993 and 8.1 in 1994, with proportionally low tiller numbers, 5.6 hill $^{-1}$ in 1992, 4.8 in 1994 and 3.8 in 1994. This was probably a result of both the poor soil and the harsh climatic conditions. Control plants on-station and on-farm showed a similar partitioning of dry weight between stems and leaves, and both had already formed two-thirds of their total tillers at 35 DAS. In the two experiments plant development was similar, though on a smaller-scale on-farm. Adamou (1994) and Diouf (1990) reported that small plants, weighing approxi- 
Table 1. Yield and yield components of pearl millet with and without drought stress, in two experiments, on-station and on-farm, under different levels of nitrogen $(\mathrm{N})$, phosphorus $(\mathrm{P})$ and potassium $(\mathrm{K})$ fertilization

\begin{tabular}{|c|c|c|c|c|c|c|c|c|c|}
\hline & \multirow{2}{*}{\multicolumn{2}{|c|}{$\begin{array}{c}\text { On-station } \\
\text { NPK }\end{array}$}} & \multicolumn{7}{|c|}{ On-farm } \\
\hline & & & \multicolumn{3}{|c|}{$P$} & \multicolumn{3}{|c|}{ NP } & \multirow[b]{2}{*}{$\begin{array}{l}\text { Year } \\
\text { effect }\end{array}$} \\
\hline & Control & Stress & $\begin{array}{c}\text { Gontrol } \\
1992\end{array}$ & $\begin{array}{c}\text { Stress } \\
1993\end{array}$ & $\begin{array}{c}\text { Stress } \\
1994\end{array}$ & $\begin{array}{c}\text { Control } \\
1992\end{array}$ & $\begin{array}{c}\text { Stress } \\
1993\end{array}$ & $\begin{array}{c}\text { Stress } \\
1994\end{array}$ & \\
\hline Hills $\left(\mathrm{ha}^{-1}\right)$ & 10000 & 10000 & 8590 & 9550 & 8240 & 8830 & 9400 & 8680 & $* *$ \\
\hline Grain yield $\left(\mathrm{kg} \mathrm{ha}^{-1}\right)$ & 678 & 234 & * 693 & 204 & 266 & 829 & 342 & 351 & $* * *$ \\
\hline Panicles with grain $\left(\right.$ hill $\left.^{-1}\right)$ & 4.77 & 3.00 & 3.05 & 2.59 & 2.34 & 3.95 & 3.11 & 2.74 & ns \\
\hline Grains (panicle ${ }^{-1}$ ) & 2192 & 1060 & * 2789 & 1140 & 1338 & 2567 & 1475 & 1523 & $* * *$ \\
\hline Single grain mass (mg) & 6.84 & 5.35 & 9.45 & 7.31 & 9.77 & 9.10 & 8.18 & 9.12 & $* *$ \\
\hline Total production $\left(\mathrm{kg} \mathrm{ha}^{-1}\right)$ & 4332 & 2637 & * 2450 & 1980 & 1350 & $3470 \quad 2$ & 2480 & 1500 & * \\
\hline Harvest index $(\%)$ & 16 & 9 & 28 & 10 & 20 & 24 & 14 & 23 & \\
\hline
\end{tabular}

$* * * * *$ and $*$ denote significance at $p<0.001,0.01,0.05$ respectively.

mately $4.9 \mathrm{~g} \mathrm{hill}^{-1}$ at $35 \mathrm{DAS}$, were resistant to drought and were still able to produce grain yields of $500-800 \mathrm{~kg} \mathrm{ha}^{-1}$ provided that the stress was not too severe.

In both experiments control plots yielded about $700 \mathrm{~kg} \mathrm{ha}^{-1}$ and drought stress reduced grain yield by approximately two-thirds (Table 1). The yield component primarily responsible for yield reduction in both trials was number of grains per panicle; components least affected were single-grain mass and number of hills $\mathrm{ha}^{-1}$. It was concluded that floral initiation and flowering were much more disrupted by drought than were grain filling and hill survival. In both trials the impact of drought on total above-ground biomass or crop residue was less pronounced. Biomass production was superior in the on-station trial compared with the on-farm trial, both in control and stressed plants due to better overall nutrition. In the on-farm trial, the harvest index was therefore low. The extra nitrogen applied in the on-station trial was used partly to increase grain yield (20\% increase in $1992,68 \%$ in 1993 and $32 \%$ in 1994) and partly to produce extra leaves and stem (85\% more crop residue in 1992, 19\% in 1993 and $3 \%$ in 1994). Grain yield was improved mainly by an increase in panicle number, but this was not statistically significant.

\section{Flowering (1)}

The flowering of panicles followed a logistic growth-curve, though the S-shape was less visible with the on-farm data mainly because observations were less frequent. In the on-station experiment (Fig. 4a) the appearance of flowering panicles was similar in control and stressed pants up to 54 DAS, suggesting that the floral initiation of the latter was probably completed before stress occurred. During the following $7 \mathrm{~d}$ (55-62 DAS), the flowering of new panicles in the 
(a)

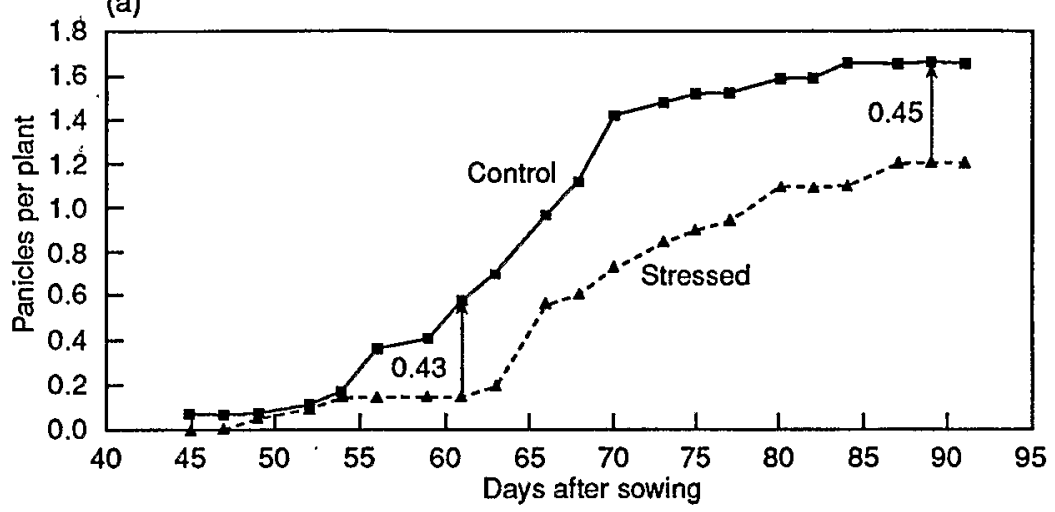

(b)

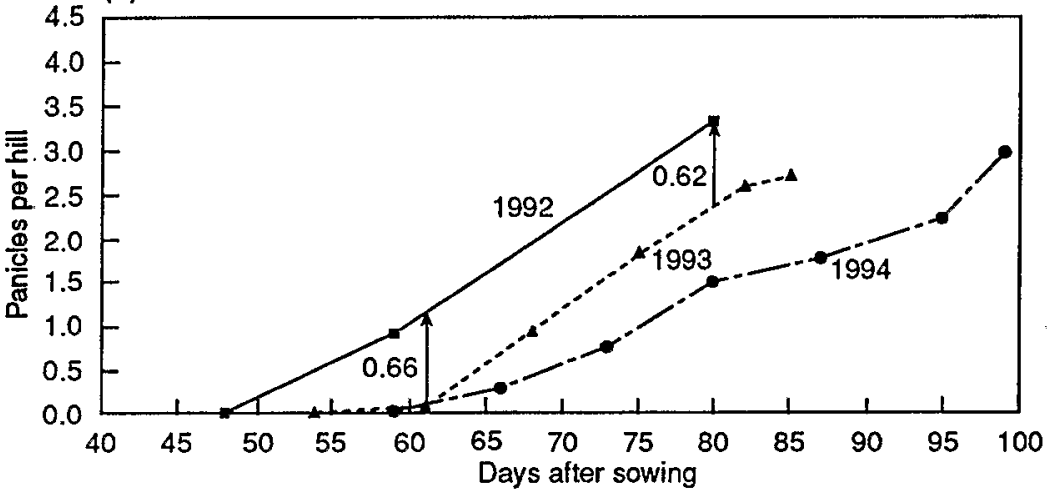

(c)

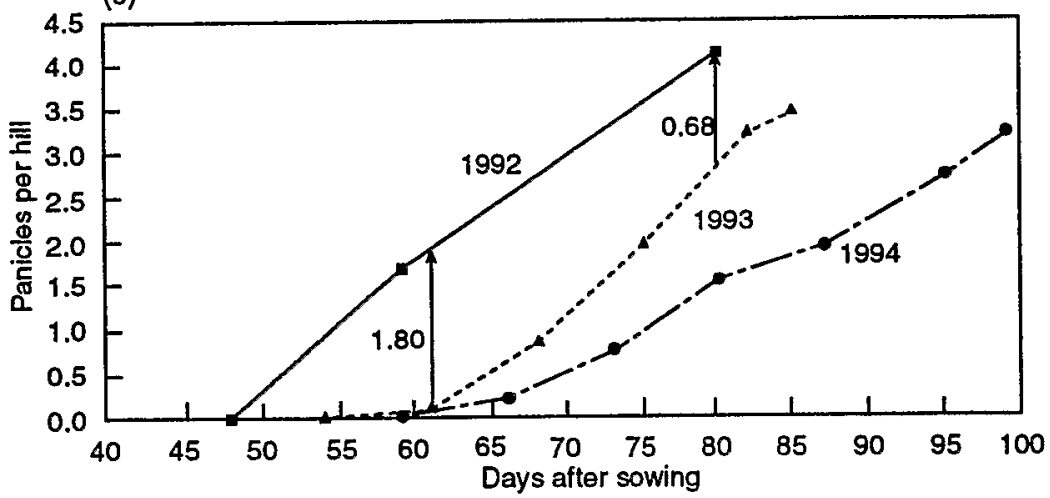

Fig. 4. Successive appearances of flowering panicles in relation to days after sowing (a) on-station with nitrogen, phosphorus and potassium fertilizer (data per plant), (b) on-farm with phosphorus fertilizer (data per hill) and (c) on-farm with nitrogen and phosphorus fertilizer (data per hill). 
stressed plants ceased. This indicated that the panicles normally flowering at this period were initiated during severe stress, suffering from no irrigation during 35-50 DAS. Irrigation for $12 \mathrm{~d}$ was necessary before flowering could resume. During the period of near-constant flowering, panicles appeared at a slightly lower rate in the stressed plants (about 1 panicle hill ${ }^{-1}$ every $5.3 \mathrm{~d}$ compared with 1 panicle hill ${ }^{-1}$ every $4.8 \mathrm{~d}$ in the control plants). The difference in the total number of panicles between control and stressed plants $\left(0.45\right.$ panicle plant $\left.{ }^{-1}\right)$ was ascribed entirely to the difference in panicle number at 61 DAS $(0.43$ panicle plant ${ }^{-1}$ ). No statistically significant difference was found between control and stressed plants with regard to delay in flowering (number of days necessary to reach near constant flowering rate), flowering rate (the cumulative increase of flowering panicles described as the slope of the straight line during 10-90\% flowering), and total number of panicles.

The successive emergence of panicles was analysed in a similar way in the onfarm experiment. For the millet plots that did not receive nitrogen applications (Fig. 4b) a serious delay in flowering occurred in 1993 and 1994 (statistically significant at $p<0.01$ ) compared with 1992 due to pre-floral drought. In 1992 and 1993 little difference occurred in the rate at which panicles appeared when the rate was near constant at approximately 1 panicle hill ${ }^{-1}$ every $9 \mathrm{~d}$. In 1994 the flowering rate decreased to 1 panicle hill ${ }^{-1}$ every $12 \mathrm{~d}(p<0.05)$ but this was caused not by drought but by excessive precipitation that damaged the plants and leached nutrients. The difference in total numbers of panicles per hill between 1992 and 1993 was 0.62 which was explained by the difference in panicle number at 61 DAS (0.66). Application of nitrogen resulted in more panicles per hill (Fig. $4 \mathrm{c}$ but flowering did not start earlier, nor did it continue for a longer period. Consequently, the flowering rate was stimulated by nitrogen application, reaching approximately 1 panicle hill ${ }^{-1}$ every $8 \mathrm{~d}$ in 1992, and every $7 \mathrm{~d}$ in 1993. In 1994 little difference was observed due to leaching. The difference in total numbers of panicles per hill between 1992 and 1993 was 0.68 , but this difference was 1.80 at 61 DAS. Nitrogen application had a beneficial effect in most years, but was never statistically significant.

\section{Flowering (2)}

The relation between the flowering period and stand variability presented in Fig. $4 \mathrm{a}$ is also shown in Table 2. Here, 18 control plants and 19 stressed plants are presented; three plants were eliminated because they were outcrossing with wild millet. Among the control plants, groups of early-, intermediate- and late-flowering plants were distinguished, comprising three, eight and six plants respectively. Likewise, the stressed plants could be divided into early-, intermediate- and lateflowering plants. The groups of early- and late-flowering plants had approximately the same size as the control groups and their flowering period remained largely unaffected by the drought period. The group of intermediate-flowering plants comprised only two plants, whereas the number of sterile plants had increased to eight. The group of intermediate-flowering plants was affected most 
Table 2. Flowering of millet plants in the control and stress treatments on-station. ( $F=$ main stem, $\mathrm{T}=$ tillers $)$

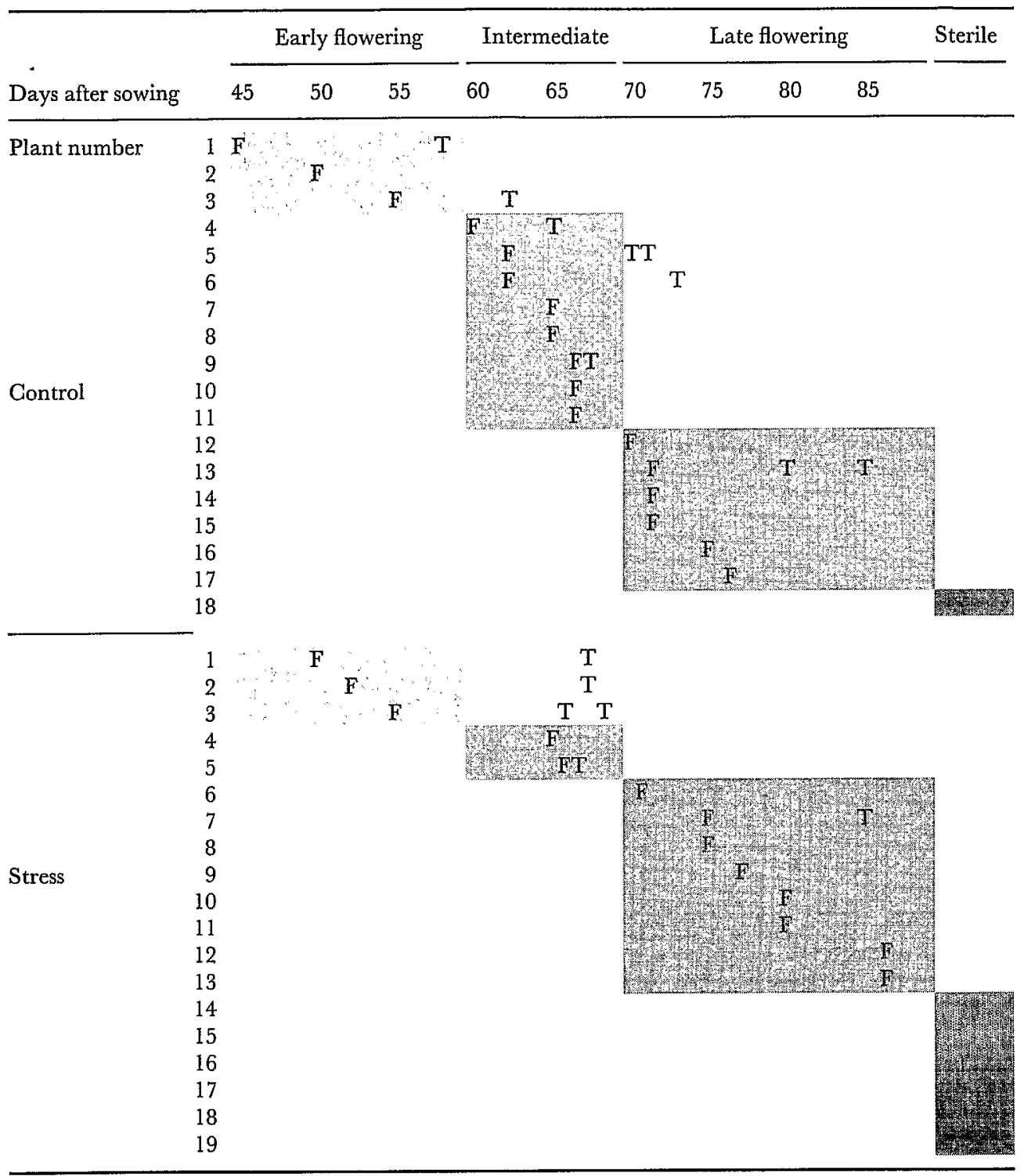

by the drought stress to the point where the majority of plants became sterile. Despite the small size of the sample, Table 2 reveals two mechanisms of drought avoidance. First, the groups of early- and late-flowering millet just happened to flower outside the period of drought. Secondly, among the group of earlyflowering plants, some plants were able to produce some grain by delaying the flowering of tillers beyond the drought period.

In the on-farm experiment it was possible to separate the millet population into 


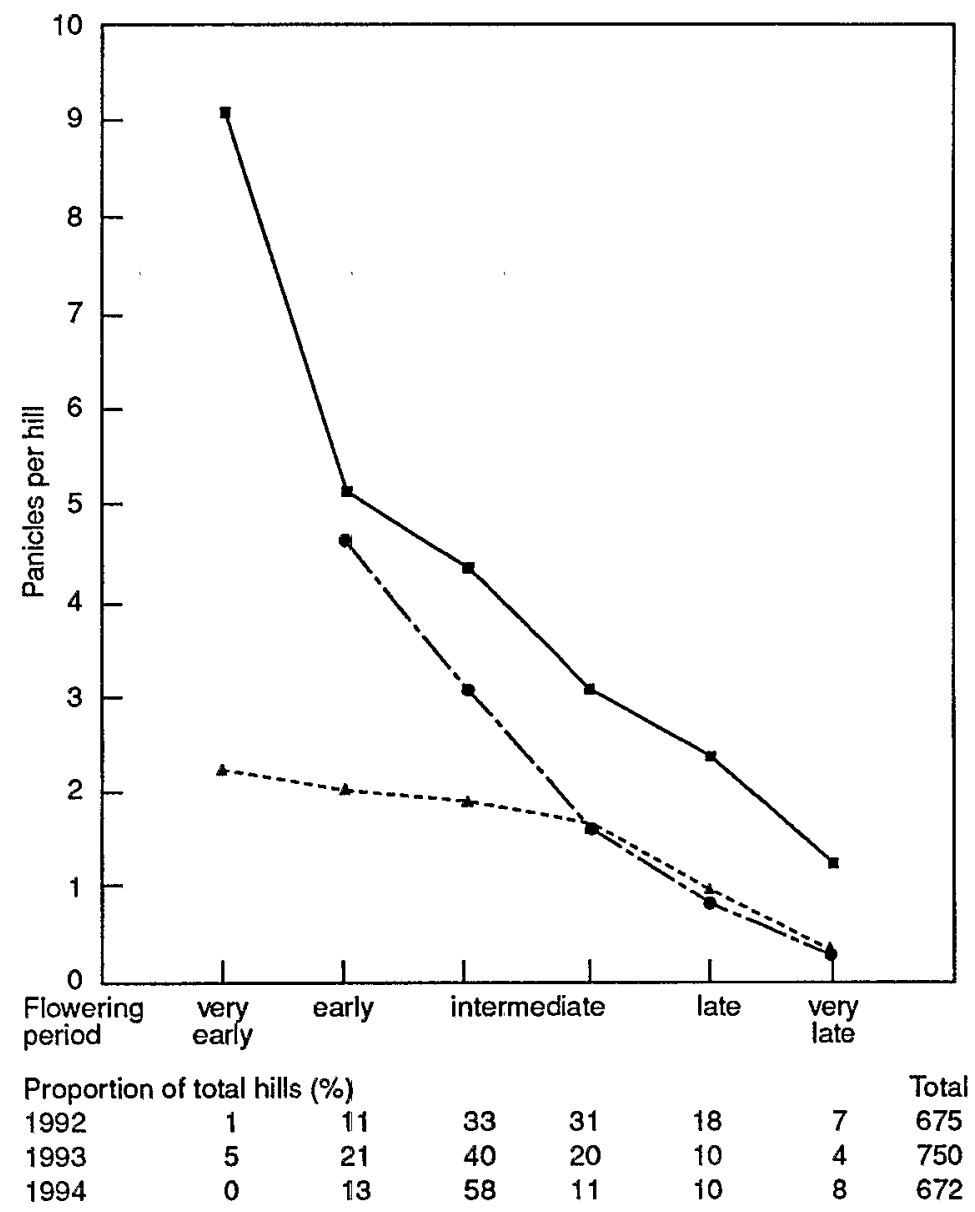

Fig. 5. On-farm, mean number of panicles per hill at 80 days after sowing in relation to flowering period of hills, with proportions of total number of hills for the three years $(-[-1992 ; \cdots \cdots 1993$; 1994).

early-, intermediate- and late-flowering hills because all hills had received a development score shortly after thinning and there was a close relationship between this score and the total number of panicles. The relation between development score and maximum hill height at 80 DAS was less strong because most hills approached the same maximum height, only late- and very lateflowering hills were shorter. In general, in 1992 and 1994, the earlier the flowering the more panicles could be produced (Fig. 5). In 1993, however, very early- and early-flowering hills did not develop more panicles. The point at which these hills entered the generative growth stage coincided with the onset of a drought period (25-45 DAS) and, subsequently, the panicles of the early-flowering plants were affected by the drought. In 1994, the dry period at 20-35 DAS prevented the development of very early-flowering hills. The proportion of early- and very earlyflowering hills in the stand (Fig. 5) reflected the abundance of very early rainfall, 


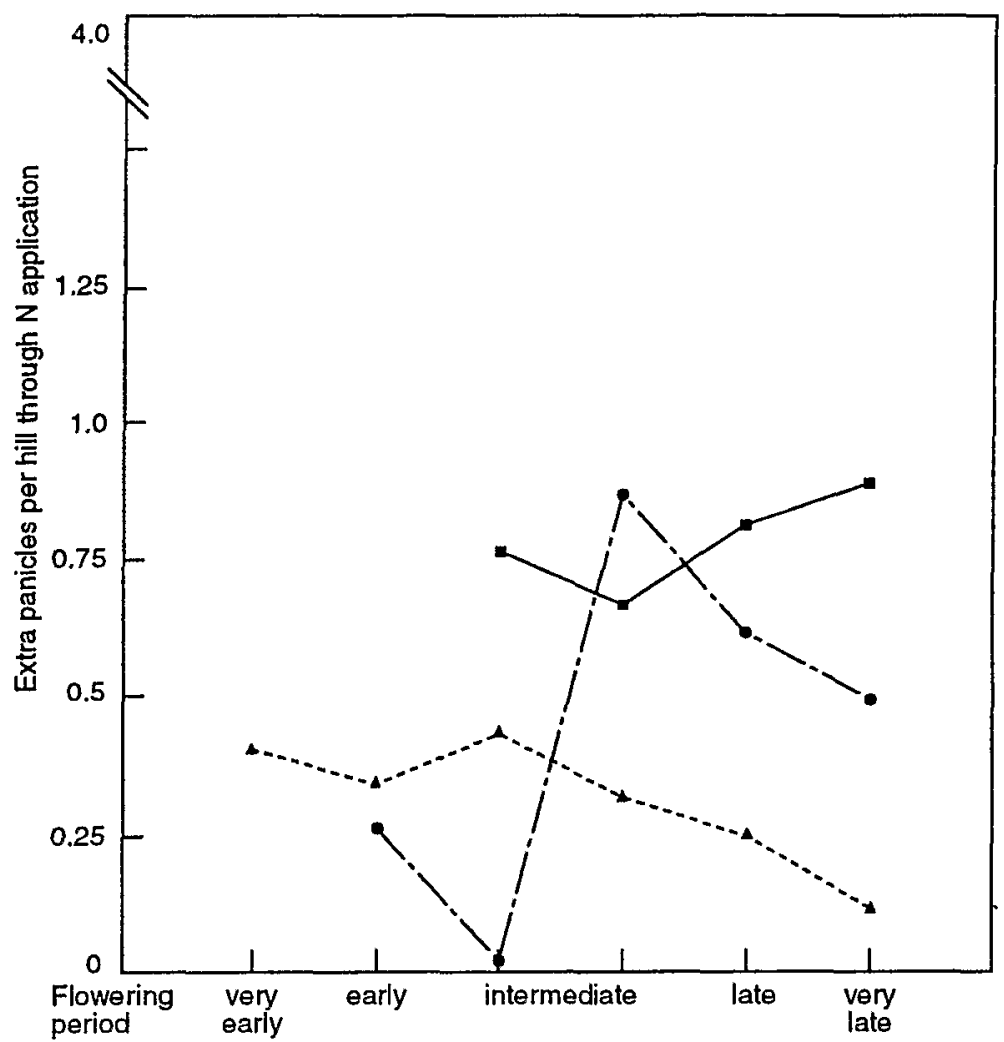

Fig. 6. On-farm, difference in panicle number at 80 days after sowing between hills with and without nitrogen (N) fertilization by hills flowering during different periods, for the three years of the experiment $(-1992 ; \cdots \cdot 1993 ;-1994)$.

resulting in $41 \mathrm{~mm}$ water in the $0-80 \mathrm{~cm}$ soil layer in $1992,73 \mathrm{~mm}$ in 1993 and 30 $\mathrm{mm}$ in 1994 at 15 DAS.

The effect of nitrogen application on flowering period resulted primarily in more panicles per hill being produced in the same period. Since the number of stems was determined early in the life of the crop, prior to the first application of urea, the extra nitrogen applied was used to increase the number of fertile stems rather than the total number of stems. In 1992, the average increase in panicle number of intermediate- and late-flowering hills was 0.8 hill $^{-1}$ (Fig. 6). The very early-flowering hills, only $0.5 \%$ of the stand, produced 4 extra panicles per hill. In the same year, the group of early-flowering hills did not benefit from extra nitrogen because the first application of urea was accidentally sprayed over the soil surface, instead of being incorporated into the topsoil. This group of relatively large plants probably suffered most from the urea touching and burning the leaves. The less developed hills were still too small and in the more advanced hills internodes had elongated and the larger leaves were clear of the ground. In 1993, the first application of nitrogen was used effectively to increase panicle number on early- and intermediate-flowering hills, but later-flowering hills did not benefit 
much from the second application, probably because the soil was too dry at that time (60 DAS). In 1994, no extra panicles were produced by the early-flowering hills, probably because the first application of urea was followed by heavy rainstorms that leached it away. The later-flowering hills benefited from the second nitrogen application.

The dry periods in 1993 and 1994 did not prevent hills from flowering. In 1992 $96 \%$ of hills were fertile, in $199396 \%$ and in $199488 \%$. This was probably attributed to the different plants in the same hill. Although some plants could become sterile the less advanced plants could flower later and still produce some grain.

\section{DISGUSSION AND CONGLUSION}

In drought-prone areas, the risk of failure for seed crops is maximal when drought occurs during the period of flower initiation and flowering. Therefore, the development of the main stem panicle coincides with a period of increasing probability of rainfall thus reducing high risk (Sivakumar, 1992). This is not sufficient in Sahelian rain-fed agriculture. Pearl millet is the only tall cereal where selection does not eliminate tillering (Siband, 1981). In millet, each tiller is determinate but tillering may extend over a relatively long period. In that case, later or earlier tillers may compensate for losses from the main stem. Consequently, many studies of drought have focused on tillering since, under high fertility and abundant irrigation, high tillering millet plants can be obtained (Mahalakshmi and Bidinger, 1985; 1986; Mahalakshmi et al., 1987). These onstation studies in India investigated the effect of water deficit during panicle development and reported a delay in flowering as well as a grain loss on the main shoot as a result of drought. Losses were, however, fully compensated for by an increase in grain yield on tillers. Our findings in Niger did not confirm this. First, stress was probably less severe in India because of the higher water-holding capacity of the soil compared with the sandy Sahelian soils. Consequently, all main shoots of the stressed plants remained fertile in India, whereas one-third of them became sterile in our on-station experiment. Secondly, in India irrigation was resumed after the drought, which could have artificially lengthened the life of stressed plants and thus provided ample opportunities for tiller growth since soil fertility remained high. This was in contrast to our experiment where soil fertility stayed relatively low and irrigation regimes simulated the natural rainfall pattern with progressive reduction in irrigation towards the end of the season. Both conditions limited the production of fertile tillers.

The advantage of on-station research lies in the correct identification of factors controlling plant growth and development. In recent years concern has increased for validation of experimental station research in farmers' production fields, but there are two main obstacles. First, the gap in grain yield and biomass that separates the production level obtained on the experimental station and by local farmers has to be overcome. This can be done, as in our trials, by striving for 
similar cultivation conditions. We found that grain yield and grain number suffered with equally serious losses in both cases, and we concluded that reproductive units were lost chiefly because their initiation and development coincided with periods of water deficit. The second obstacle cannot usually be checked in published data and it occurs when taking an average or a model value when the range is more important. In agrophysiological studies the sample data are pooled in order to describe the behaviour of the average plant under drought stress. What remains hidden is the fact that the sample of experimental plants is likely to consist of a group of early- and late-flowering plants and these sub-groups have a different response to drought, some experimental plants developing, others becoming sterile.

In our results agrophysiological and agronomical aspects complement each other. Under farm conditions and at low fertility levels on-station, the possibilities for tiller compensation are restricted to the early- and very early-flowering plants. Only these plants produce fertile tillers in sufficient numbers. Being more advanced than other plants in the stand, they possess a resilience or elasticity that allows them to stretch the reproductive phase from about 13 to 18 days. It is precisely this elasticity that is meant by development plasticity (Ludlow and Muchow, 1988) and the duration of the flowering period depends on the extent of water deficits. Later-flowering plants do not have this potential because the development of fertile tillers is greatly reduced, both by poor soil and the short duration of the rainy season. Consequently, a dry spell during panicle initiation or flowering can cause a whole generation of plants to become sterile. Yet other plants in the same hill will compensate for the losses because they can flower outside the period of drought. As a result, the number of fertile hills remains largely unaffected by drought. The duration of the flowering period of a small population of 18 plants (on-station) or a stand of about 700 hills (on-farm) is not much affected by drought either. In both cases flowering extended over approximately $40 \mathrm{~d}$.

The best risk-reducing strategy for pearl millet farmers in the Sahel is to spread the sensitive stages in crop development over as long a period as possible. The phenological spread is introduced by the genetic variation and is further encouraged by cultivation, namely, hill planting, replanting, spacing, and probably thinning and weeding, though the exact contribution of these practices to stand variability remains to be determined. Since drought avoidance is retained in a variable stand of early-, intermediate- and late-flowering plants, all practices that reduce stand variance will, in theory, automatically contribute to increased risk. Indeed, better management usually reduces the variability in farmers' millet fields (Buerkert et al., 1995; Rockström and de Rouw, in press). However, better crop care will first decrease the number of unvegetated and sterile hills. Second, there will be a shift towards taller hills with increased biomass and more uniform height. Third, as far as early plant vigour can be stimulated by better infiltration and abundant nutrients for young plants, the sub-population of early-flowering and high-tillering millet plants will increase. Even by homogenizing the environ- 
ment at the level of on-station plots, using traditional varieties, the spread in early-, medium- and late-flowering plants will be preserved. Stand variability, with the farming practices which contribute to it, appears of paramount importance in accounting for drought avoidance.

Acknoweledgements. We wish to thank Sylvie Galle (ORSTOM) and Bill Payne (ICRISAT) for kindly providing the soil water data, as well as Ramun Kho (ICRAF) for statistical advice.

\section{REFERENGES}

Adamou, M. (1994). Analyse et Modélisation de l'Évaporation-transpiration d'une Culture de Mil en Région Aride Sahélienne. Thèse de doctorat. Université Paris-sud XI Orsay.

Azam-Ali, S. N., Gregory, P. J. \& Monteith, J. L. (1984). Effects of planting density in water use and productivity of pearl millet (Pennisetum typhoides) grown on stored water. II. Water use, light interception and dry matter production. Experimental Agriculture 20:215-224.

Brouwer, J., Fussell, L. K. \& Herrmann, L. (1993). Soil and crop growth micro-variability in the West African semi-arid tropics: a possible risk-reducing factor for subsistence farmers. Agriculture, Ecosystems and Environment 45:229-238.

Buerkert, A. \& Stern, R. D. (1995). Effects of crop residue and phosphorus application on the spatial variability of non-destructively measured millet growth in the Sahel. Experimental Agriculture 31:429449.

Buerkert, A., Stern, R. D. \& Marschner, H. (1995). Post stratification clarifies treatment effects on pearl millet growth in the Sahel. Agronomy Journal 87:752-761.

Bourke, D. O'D. (1963). The West African millet crop and its improvement. Soils Africains 8:121-132.

Carberry, P. S., Campbell, L. C. \& Bidinger, F. R. (1985). The growth and development of pearl millet as affected by plant population. Field Crops Research 11:193-205.

Chase, R. G., Wendt, T. W. \& Hossner, L. R. (1989). A study of crop growth variability in sandy sahelian soils. In: Soil, Crop, and Water Management Systems for Rainfed Agriculture in the Sudano-Sahelian Zone, 229240 (Eds C. Renard, R. J. Vanderbeldt \& J. F. Parr). Patancheru, India: ICRISAT.

Chopart, J.-L. (1980). Etude au champ des systèmes racinaires des principales cultures pluviales au Sénégal (arachide, mil, sorgho, riz pluvial). Thèse de docteur de l'INP de Toulouse.

Diouf, M. (1990). Analyse de l'Élaboration du Rendement du Mil (Pennisetum typhoides Stapf et Hubb.) Mise au Point d'une Méthode de Diagnostic en Parcelles Paysannes. Thèse de doctorat, Institut National Agronomique Paris-Grignon.

Do, F., Winkel, T., Cournac, L. \& Louguet, P. (1996). Impact of late-season drought on water relations in a sparse canopy of millet (Pennisetum glaucum (L.) R. Br.). Field Crops Research 48:103-113.

Garg, B. K., Kathju, S., Vyas, S. P. \& Lahiri, A. N. (1993). Effect of plant density and soil fertility in pearl millet under drought and good rainfall situations. Annals of Arid Zone Research 32:13-20.

Geiger, S. C. \& Manu, A. (1993). Soil surface characteristics and variability in the growth of millet in the plateau and valley region of Western Niger. Agriculture, Ecosystems and Environment 45:203-211.

Gross, L. J. (1989) Plant physiological ecology: a theoretician's perspective. In: Perspectives in Ecological Theory, 11-24 (Eds J. Roughgarden, R. M. May \& S. A. Levin). Princeton, New Jersey: Princeton University Press.

INRAN (Institut de Recherche Agronomique du Niger) (1987). Catalogue des variétés recommandées de mil, sorgho, niébé et autres cultures du Niger. Rapport liaison Recherche-Vulgarisation, Niamey, Niger.

Jouve, P. (1991). Sécheresse au Sahel et stratégies paysannes. Sécheresse 2:61-69.

Klaij, M. C. \& Hoogmoed, W. B. (1993). Soil management of crop production in the West African Sahel. II. Emergence, establishment and yield pearl millet. Soil \& Tillage Research 25:301-315.

Korner, C. M., ScheeI, J. A. \& Bauer, M. (1979). Maximum leaf diffusive conductance in vascular plants. Photosynthetica 13:45-82.

Kowal, J. M. \& Kassam, A. H. (1978) Agricultural Ecology of Savanna. A Study of West Africa. Oxford: Clarendon Press. 
Lammers, J. P. A. \& Feil, P. R. (1995). Farmers' knowledge and management of spatial soil and crop growth variability in Niger, West Africa. Netherlands Joumal of Agriculiural Science 43:375-389.

Ludlow, M. M. \& Muchow, R. C. (1988). Critical evaluation of the possibilities for modifying crops for high production per unit of precipitation. In Drought Research Priorities for the Dry Land Tropics, 179-211. (Eds F. R. Bidinger \& G. Johansen). Patancheru, India: ICRISAT.

Mahalakshmi, V. \& Bidinger, F. R. (1985). Water stress and time of floral initiation in pearl millet. Fournal of Agricultural Science, Gambridge 105:437-445.

Mahalakshmi, V. \& Bidinger, F. R. (1986). Water deficit during panicle development in pearl millet: yield compensation by tillers. Fournal of Agricultural Science, Cambridge 106:113-119.

Mahalakshmi, V., Bidinger, F. R. \& Raju, D. S. (1987). Effect of timing of water deficit on pearl millet (Penniselum americanum). Field Crops Research 15:327-339.

Maiti, R. K. \& Bidinger, F. R. (1981). Growth and development of the pearl millet plant. ICRISAT Research Bulletin 6:2-14.

McIntire, J. \& Fussell, L. K. (1989). On-farm experiments with millet in Niger: crop establishment, yield loss factors and economic analysis. Experimental Agriculture 25:217-233.

Pearson, C. (1984). Pennisetum millet. In The Physiology of Tropical Field Crops, 281-304 (Eds P. R. Goldsworthy \& N. M. Ficher). Chichester: John Wiley \& Sons Ltd.

Rockström, J. \& Rouw, de A. (1997). Water, nutrients and slope position in on-farm pearl millet cultivation in the Sahel. Plant and Soil (in press).

Seetharama, N., Mahalakshmi, V., Bidinger, F. R. \& Sardar Singh (1984). Response of sorghum and pearl millet to drought stress in semi-arid India. In Agrometeorology of Sorghum and Millet in the Semi-arid tropics, 159-173. Patancheru, India: ICRISAT.

Siband, P. (1981). Croissance, Nutrition et Production du Mil (Pennisetum typhoides Hubb. \& Stapf). Essai d'Analyse du Fonctionnement du Mil en Zone Sahéllienne. Thèse de doctorat, Université de Languedoc, Montpellier.

Siband, P. (1983). Essai d'analyse du fonctionnement du mil (Pennisetum typhoides)en zone sahélienne. Agronomie Tropicale 38:27-35.

Sivakumar, M. V. K. (1989). Agroclimatic aspects of rainfed agriculture in the Sudano-sahelian zone. In: Soil, Crop, and Water Management Systems for Rainfed Agriculture in the Sudano-Sahelian Zone, 17-38 (Eds C. Renard, R. J. Vanderbeldt, \& J. F. Parr). Patancheru, India: ICRISAT.

Sivakumar, M. V. K. (1992). Climate change and implications for agriculture in Niger. Climatic Change 20:297-312.

Soegaard, H. \& Boegh, E. (1995). Estimation of evapotranspiration from a millet crop in the Sahel combining sap flow, leaf area index and eddy correlation technique. Fournal of Hydrology 166:265-282.

Squire, G. R., Gregory, P.J., Monteith, J. L., Russell, M. B. \& Piara Singh. (1984). Control of water use by pearl millet (Pennisetum typhoides). Experimental Agriculture 20:135-149.

Squire, G. R., Marshall, B. \& Ong, C. K. (1986). Development and growth of pearl millet (Pennisetum typhoides) in response to water supply and demand. Experimental Agriculture 22:289-299.

Traoré, M.-F. (1974). Etude de la fumure minérale azotée intensive des céréales et du role spécifique de la matière organique dans la fertilité des sols au Mali. Agronomie Tropicale 29:567-586.

Wallace, J. S., Roberts, J. M. \& Sivakumar, M. V. K. (1990). The estimation of transpiration from sparse dry land millet using stomatal conductance and vegetation area indices. Agricultural and Forest Meteorology 51:35-49.

Winkel, T. \& Do, F. (1992). Caractères morphologiques et physiologiques de résistance du mil (Pennisetum glaucum (L.) R. Br.) à la sécheresse. Agronomie Tropicale 46:339-351.

Winkel, T., Renno, J.-F. \& Payne, W. A. (1997). Effect of the timing of water deficit on growth, phenology and yield of pearl millet (Pennisetum glaucum (L.) R. Br.) grown in Sahelian conditions. Journal of Experimental Botany 48:1001-1009. 